\title{
PENENTUAN AWAL DAN DURASI MUSIM KEMARAU MENGGUNAKAN FUNGSI POLYNOMIAL DENGAN APLIKASI VISUAL BASIC FOR APPLICATIONS (VBA)
}

\author{
DETERMINATION OF DRY SEASON ONSET AND DURATION USING POLYNOMIAL FUNCTION \\ WITH VISUAL BASIC FOR APPLICATIONS (VBA)
}

\author{
Fadli Irsyad $^{1 *}$, Satyanto Krido Saptomo ${ }^{2}$, Budi Indra Setiawan ${ }^{2}$ \\ ${ }^{1}$ Program Studi Teknik Pertanian, Universitas Andalas, Padang \\ ${ }^{2}$ Departemen Teknik Sipil dan Lingkungan, Institut Pertanian Bogor, Bogor 16680 \\ * Corresponding author, email: fadliirsyad_ua@yahoo.com
}

Penyerahan Naskah: 16 Juli 2013

Diterima untuk diterbitkan: 6 Mei 2014

\begin{abstract}
Forecasting the occurrence of the onset of dry season and its length is important in determining the availability of water for irrigation, domestic and industrial uses. The length of dry season is used for reference in calculating water demand. Prediction of drought can be studied based on the rainfall patterns that have occurred. This is possible because there is a tendency that the rain will repeat a certain pattern at a certain time. The purpose of this study was to predict the onset of dry and rainy seasons as well as their length. Determination of the onset of dry season and its length was conducted using polynomial function of the cumulative amount of rain every single day based on the rain data. The research was conducted using rainfall data from Climate Station III in Serang from 1989 to 2010. The sum of daily rainfall could form a polynomial function. If the magnitude of daily rainfall in a certain period of time is less than the slope of the cumulative annual rainfall, then at that time the dry season is occurred. Determination of the dry season peak can be done by finding the maximum (extreme) point from the polynomial function by getting the second derivative which value is close or equal to zero. In average, the dry season occurred in Serang city started on the 132nd until 300th day. Deviation value for the onset of dry and rainy seasons were 23 and 38 days, respectively, with an average of length of 168 days. The average of $R 2$ value for polynomial function was 0.9937.
\end{abstract}

Keywords: dry season, length of dry season, Visual Basic for Applications (VBA), Serang climatology

Sitasi: Irsyad F., Saptomo S.K. dan Setiawan B.I. 2014. Penentuan awal dan durasi musim kemarau menggunakan fungsi polynomial dengan aplikasi Visual Basic for Application (VBA). J Agromet Indonesia. 28(1):40-46.

\section{PENDAHULUAN}

Penentuan musim di wilayah Indonesia oleh Badan Meteorologi Klimatologi dan Geofisika (BMKG) dilakukan dengan cara menganalisis data curah hujan observasi permukaan dalam periode dasarian, yaitu rentang waktu selama 10 (sepuluh) hari. Dalam satu bulan dibagi menjadi 3 dasarian, yaitu Dasarian 1 dimulai dari tanggal 1 sampai dengan 10, dasarian 2 dimulai tanggal 11 sampai dengan 20 dan dasarian 3 dimulai tanggal 21 sampai dengan akhir bulan (BMKG, 2010). Berdasarkan ketentuan yang dibuat oleh BMKG, Awal Musim Hujan (AMH) ditandai dengan jumlah curah hujan dasarian lebih dari $50 \mathrm{~mm}$ dan diikuti minimal dua dasarian berikutnya. Sebaliknya awal musim kemarau ditandai dengan jumlah curah hujan dasarian kurang dari $50 \mathrm{~mm}$ dan diikuti minimal dua dasarian berikutnya.

Definisi AMH dapat juga bergantung pada kondisi wilayah lokal untuk bidang pertanian. Untuk kepentingan sektor pertanian, AMH adalah informasi yang penting dalam penentuan waktu dan pola tanam. Definisi AMH yang digunakan pada bidang pertanian di Indonesia, apabila curah hujan setelah 1 Agustus tercatat lebih dari $40 \mathrm{~mm}$ dalam 5 hari berturut-turut tanpa diikuti 10 hari dry spell atau curah hujan kurang dari $5 \mathrm{~mm}$ dalam periode 10 hari (Moron et al., 2008). 
Di daerah yang memiliki iklim kering dan basah, penentuan masa dan lama musim tanam sangat dipengaruhi oleh ketersediaan air. Curah hujan (P) dan evapotranspirasi (PE) adalah parameter yang menjadi syarat dalam menentukan musim tanam (Bello et al., 2010). Salah satu masalah utama bagi petani adalah menentukan tanaman yang sesuai pada kondisi wilayah dan waktu tertentu (Ohara et al., 2005). Pada lahan sawah tadah hujan, penanaman dilakukan bertepatan dengan musim hujan, sedangkan saat musim kemarau lahan sawah biasanya beralih fungsi menjadi lahan pertanian lain seperti palawija dengan tingkat kebutuhan air irigasi yang lebih rendah.

Perhatian utama dalam pertanian adalah awal, akhir dan panjang musim hujan, distribusi jumlah curah hujan sepanjang tahun dan risiko kekeringan (Edoga, 2007). Prakiraan terjadinya awal dan panjang musim kering merupakan hal penting dalam menentukan ketersedian air baik untuk irigasi, domestik dan industri. Perlu upaya untuk mengantisipasi kekeringan yang terjadi jika air tersedia tidak mencukupi kebutuhan air selama musim kemarau. Panjang musim kemarau menjadi acuan dalam menghitung kebutuhan air yang harus diusahakan agar kebutuhan air terpenuhi.

Jika kondisi musim kering tidak diperhitungkan maka kekurangan air yang terjadi dapat mengakibatkan penurunan produktivitas berbagai sektor seperti industri dan pertanian. Namun jika kondisi tersebut dapat diprediksi maka kekurangan air yang terjadi dapat dicegah dengan berbagai cara, seperti dengan mengadakan embung, waduk, dan lainnya.

Prediksi kekeringan dapat dipelajari berdasarkan interaksi iklim terkait dengan pola hujan yang pernah terjadi. Hal ini dapat dilakukan karena ada kecenderungan hujan akan berulang mengikuti pola tertentu pada kurun waktu tertentu.

Bagi instansi penyedia air baku, analisis waktu dan durasi peralihan musim kering perlu dilakukan terkait dengan pengalokasian air yang akan didistribusikan. Hal ini dimaksudkan agar jika terjadi kekurangan air, upaya penanggulangan dapat dilakukan dengan menambah sumber air alternatif atau dengan cara meningkatkan kemampuan penyimpanan air tanah.

Musim kemarau juga terkait erat dengan kebakaran hutan. Kebakaran di Indonesia sering terjadi pada bulan-bulan kering antara Juni sampai September (Chandra et al., 1998). Bencana kebakaran hutan dan lahan sangat rentan terjadi pada saat tersebut, sehingga perlu dilakukan penyelidikan untuk mendapatkan hubungan antara kekeringan dengan terjadinya kabut/asap (Robert et al., 2004).
Tujuan dari penelitian ini adalah memperkirakan awal musim kemarau dan musim hujan serta panjang musim kemarau dan musim hujan tersebut.

Banyak metode yang dapat dilakukan untuk menentukan awal dan panjang musim kering. Dalam model ini penentuan awal dan panjang musim kering ditentukan berdasarkan fungsi polinomial dari jumlah kumulatif hujan tiap satu hari berdasarkan data hujan. Akumulasi hujan pada satu hari dengan hari sebelumnya hingga akhir tahun akan membentuk suatu fugsi polinomial. Metode ini sangat sederhana dan dapat diaplikasikan untuk data deret waktu (time series).

\section{METODE PENELITIAN}

Penelitian ini dilakukan dengan menggunakan data curah hujan dari Stasiun Klimatologi Kelas III Kota Serang dari tahun 1989-2010. Penentuan awal dan panjang musim kemarau dilakukan dengan menganalisis fungsi kumulatif dari curah hujan harian dalam satu tahun. Curah hujan yang terjadi di suatu daerah disusun secara kumulatif setiap tahun. Dari penjumlahan hujan harian maka akan terbentuk suatu fungsi. Salah satu kelas yang paling berguna dan terkenal dalam penggambaran fungsi himpunan bilangan real ke dalam dirinya adalah kelas polinomial aljabar, himpunan fungsinya berbentuk (Burden et al., 1989):

$P_{n}(x)=a_{n} x^{n}+a_{n-1} x^{n-1}+\ldots+a_{1} x+a_{0}$

dimana $n$ pada Persamaan (1) adalah bilangan bulat positif dan $a_{0}, \ldots, a_{n}$ adalah konstanta. Salah satu alasan penting fungsi ini karena fungsi tersebut menggunakan pendekatan kontinu dan seragam (Gambar 1). Fungsi polinomial memiliki interval dan batasan, sehingga fungsi ini dapat dijadikan acuan dalam menganalisis curah hujan harian selama satu tahun dengan nilai batasan 365 atau 366 hari (Julian days).



Gambar 1. Bentuk fungsi polinomial (Burden et al. 1989). 




Gambar 2. Curah hujan Serang tahun 1991.

Tahap pertama dalam menganalisi awal musim kemarau adalah dengan membuat hujan kumulatif, selanjutnya menghitung koefisien $\mathrm{a} 5, \mathrm{a} 4, \ldots, \mathrm{a} 1$, dan a0 pada tahun tersebut. Setelah diketahui fungsi hujan kumulatif $(\mathrm{F}(\mathrm{x}))$ maka gradien hari kering (slope) dihitung dari fungsi tersebut. Tahapan selanjutnya mencari perubahan hujan setiap hari $\left(\mathrm{F}^{\prime}(\mathrm{x})\right)$ untuk melihat hujan harian berdasarkan model polinomial, jika hasil model polinomial mendekati curah hujan harian maka model layak untuk digunakan untuk dianalisis, fungsi yang paling mendekati kondisi curah hujan Indonesia adalah polinomial orde-5.

Selanjutnya gradien hari kering (slope) yang didapatkan dibandingkan dengan hujan harian berdasarkan model, jika berada di bawah garis gradien maka dikatakan musim kering pada tahun tersebut. Namun jika menggunakan pola BMKG gradien curah hujan (slope) adalah $50 \mathrm{~mm} / 10$ hari (5 $\mathrm{mm} /$ hari). Setelah didapatkan awal musim kemarau dilanjutkan menghitung awal musim hujan dan puncak musim kemarau. Akumulasi hujan setiap harinya hingga akhir tahun akan membentuk satu fungsi dengan pola polynomial. Hal ini dapat dilihat pada Gambar 2. Fungsi hujan kumulatif dibentuk dalam julian days, sehingga diperoleh persamaan yang dapat menentukan besarnya hujan kumulatif pada saat hari ke $x(\mathrm{~F}(\mathrm{x}))$. Persamaan hujan kumulatif dapat dilihat sebagai berikut:

$$
Y=F(x)=a_{5} \cdot x^{5}+a_{4} \cdot x^{4}+a_{3} \cdot x^{3}+a_{2} \cdot x^{2}+a_{1} \cdot x+C
$$

Pada Persamaan (2) koefisien $a_{5}, a_{4}, \ldots a_{1}$ dan $C$ dapat dihitung dengan menggunakan fungsi LINEST(known_y's,known_x's,const,stats) dengan VBA, parameter known_y's merupakan nilai hujan kumulatif dan known_x's nilai Julian days.

$$
\begin{aligned}
d \text { Yval }= & \text { Worksheets }(2) \cdot \text { Range }(\text { Sheet2.Cells }(2,5 \\
& + \text { l), Sheet } 2 . \text { Cells }(367,5+l)) \\
d X v a l & =\text { Worksheets }(2) \cdot \text { Range }(\text { Sheet2.Cells }(2, \\
& 1), \text { Sheet } 2 . \text { Cells }(367,5))
\end{aligned}
$$

\section{Cells $6+l, \quad 1+k)=$ WorksheetFunction.Index(Application.Li $n E s t(d Y v a l, d X v a l), 1, k)$}

Garis $F(x)$ yang hampir datar pada Gambar 2 menandakan perubahan hujan setiap harinya sangat kecil dan jika terus menerus terjadi maka dapat dipastikan saat itu adalah musim kemarau, jika peningkatan hujan kumulatif signifikan maka saat itu berada pada musim hujan. Titik peralihan inilah (X-dry dan X-wet) yang menjadi penentu awal musim kemarau atau hujan. Penentuan kedua titik tersebut dilakukan bedasarkan gradient garis (slope) dari fungsi $F(x)$.

Fungsi hujan kumulatif $(F(x))$ memiliki slope (kemiringan). Slope tersebut dapat dihitung dengan menggunakan fungsi VBA pada Persamaan (3):

Slope $=\frac{\sum(x-\dot{x})(y-\dot{y})}{\sum(x-\dot{x})^{2}}$
Dry season gradient = WorksheetFunction.Index(Application.Li $n E s t(d$ Yval2, dXval2), 1)

Nilai ini menunjukkan pengaruh perubahan hari (x) terhadap fungsi hujan kumulatif dalam satu tahun. Besarnya nilai slope menandakan rata-rata pertambahan/pengurangan yang terjadi pada fungsi $F(x)($ Gambar 3).

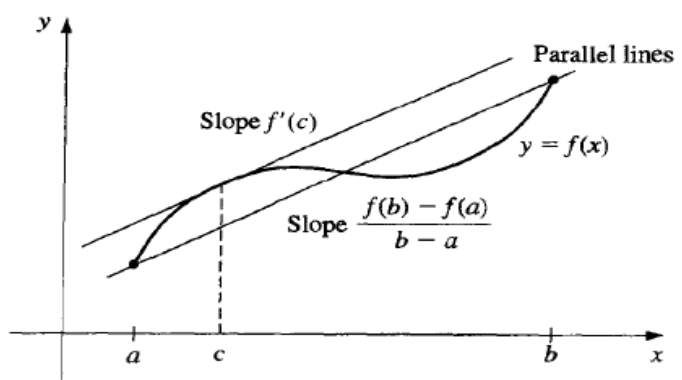

Gambar 3. Penentuan gradien fungsi polinomial (Burden et al. 1989). 
Nilai inilah yang dijadikan acuan atau batasan dalam menentukan kapan terjadinya musim kemarau dan sebaliknya. Jika besar hujan harian dalam kurun waktu tertentu lebih kecil dari slope hujan kumulatif selama satu tahun, maka pada saat itu berada pada kondisi musim kemarau.

Perubahan $F(x)$ terhadap hari akan diperoleh dengan mendapatkan turunan pertama dari Persamaan 2. Hal ini menandakan jumlah hujan pada hari tersebut berdasarkan pendekatan model pada Persamaan (4).

$F^{\prime}(x)=\frac{d y}{d x}=5 a_{5} x^{4}+4 a_{4} x^{3}+3 a_{3} x^{2}+2 a_{2} x+a_{1}$

Function FY5_I (a5, a4, a3, a2, a1, x) FY5_I $=5 * a 5 * x \wedge 4+4 * a 4 * x \wedge 3+$ $3 * a 3 * x^{\wedge} 2+2 * a 2 * x+a 1$

\section{End Function}

Awal musim kemarau dan musim hujan dapat di peroleh dengan membandingkan Persamaan (3) dengan Persamaan (4). Jika nilai $\mathrm{F}^{\prime}(\mathrm{x})<$ dari slope maka pada saat itu merupakan musim kemarau namun jika sebaliknya maka dikatakan musim hujan. Hal ini dapat dilihat pada Gambar 4.



Gambar 4. F'(x) dari fungsi hujan tahun 1991 dan gradien hari keringnya.
Penentuan puncak musim kemarau dapat dilakukan dengan mencari titik maksimum (ekstrim) dari $\mathrm{F}(x)$ yang dilakukan dengan mendapatkan turunan ke-3 $F$ "' $(x)$ yang nilai x mendekati/sama dengan nol $(F "(x) \sim 0)$ seperti pada Persamaan (5).

$$
F^{\prime \prime}(x)=\frac{d^{2} y}{d x^{2}}=20 a_{5} x^{3}+12 a_{4} x^{2}+6 a_{3} x+2 a_{2}
$$

$$
\begin{gathered}
\text { Function FY5_II (a5, a4, a3, a2, x) } \\
\text { FY5_II }=4 * 5 * a 5 * x \wedge 3+3 * 4 * a 4 * x \\
\wedge 2+3 * a 3 * 2 * x+2 * a 2
\end{gathered}
$$

\section{End Function}

\section{HASIL DAN PEMBAHASAN}

Aplikasi ini memiliki tiga tahapan, tahapan pertama Read Data, yaitu tahapan untuk pembacaan data curah hujan harian selama beberapa tahun (tergantu ketersediaan data). Tahapan berikutnya Analysis yakni penentuan koefisien $\mathrm{a}_{5}, \mathrm{a}_{4}, \ldots, \mathrm{a}_{1}$, dan $\mathrm{a}_{0}$ beserta gradient hari kering. Tahapan terakhir Report yakni perhitungan kapan terjadinya hari awal musim kemarau dan hujan setiap tahunnya. Proses penentuan awal musim dapat dilihat pada Gambar 5.

Penentuan koefisien $\mathrm{a}_{5}, \mathrm{a}_{4}, \ldots, \mathrm{a}_{1}$, dan $\mathrm{a}_{0}$ menghasilkan model polinomial yang sangat mendekati dengan kondisi hujan kumulatif yang terjadi di Kota Serang. Hal ini terlihat jelas dengan nilai $R^{2}$ rata-rata 0,9937 , dengan gradien hari kering rata-rata 4,449 $\mathrm{mm}$, hal ini dapat dilihat pada Tabel 1. Nilai gradien ini juga dipengaruhi jumlah hujan dalam satu tahun, semakin sedikit jumlah hujan tahunan maka gradiennya akan semakin kecil, begitu juga sebaliknya.

\section{DETERMINATION EARLY DRY SEASON AND DURATION USING POLYNOMIAL FUNCTION WITH VBA}

Created by: Fadli Irsyad, Satyanto Krido Saptomo, Budi Indra Setiawan

\begin{tabular}{|c|c|c|c|c|c|c|c|}
\hline Year & a5 & a4 & a3 & a2 & a1 & ao & $\begin{array}{c}\text { Dry season } \\
\text { gradient }\end{array}$ \\
\hline 1989 & 2.23E-09 & $-2.17 \mathrm{E}-06$ & 0.0009 & -0.1795 & 22.7724 & -227.5643 & 4.054 \\
\hline 1990 & $3.70 \mathrm{E}-09$ & $-3.36 \mathrm{E}-06$ & 0.0012 & -0.1977 & 20.7179 & -58.3635 & 3.829 \\
\hline 1991 & $-1.76 \mathrm{E}-09$ & $1.75 \mathrm{E}-06$ & -0.0005 & 0.0143 & 11.7114 & -44.7472 & 2.694 \\
\hline 1992 & $-3.35 \mathrm{E}-09$ & $2.92 \mathrm{E}-06$ & -0.0008 & 0.0487 & 9.2117 & 55.0341 & 4.375 \\
\hline 1993 & $1.35 \mathrm{E}-09$ & $-1.13 \mathrm{E}-06$ & 0.0004 & -0.0688 & 12.0508 & 41.5447 & 4.243 \\
\hline 1994 & $\begin{array}{l}-2.71 \mathrm{E}-09 \\
\end{array}$ & $2.57 \mathrm{E}-06$ & -0.0008 & 0.0596 & 7.8977 & $\begin{array}{l}-25.5268 \\
\end{array}$ & 2.522 \\
\hline 1995 & $6.76 \mathrm{E}-09$ & $-5.48 \mathrm{E}-06$ & 0.0016 & $\begin{array}{l}-0.2238 \\
-\end{array}$ & 24.3920 & $\begin{array}{l}-139.1440 \\
\end{array}$ & 9.087 \\
\hline 1996 & $-6.38 \mathrm{E}-10$ & $7.38 \mathrm{E}-07$ & -0.0002 & -0.0259 & 16.0865 & 9.5481 & 7.967 \\
\hline 1997 & $-1.90 \mathrm{E}-10$ & $4.02 \mathrm{E}-07$ & -0.0002 & 0.0001 & 10.3856 & 7.8969 & 3.078 \\
\hline 1998 & $-1.90 \mathrm{E}-09$ & $2.01 \mathrm{E}-06$ & -0.0007 & 0.0792 & 5.8015 & -34.4524 & 7.067 \\
\hline 1999 & $-2.54 \mathrm{E}-09$ & $2.77 \mathrm{E}-06$ & -0.0009 & 0.0745 & 11.3917 & 48.3775 & 6.019 \\
\hline 2000 & $-1.71 \mathrm{E}-09$ & $1.70 \mathrm{E}-06$ & -0.0005 & 0.0300 & 10.5612 & -8.2709 & 4.624 \\
\hline 2001 & $-9.19 E-10$ & $5.05 \mathrm{E}-07$ & 0.0002 & $\begin{array}{l}-0.1324 \\
\end{array}$ & 27.7880 & -128.6383 & 6.950 \\
\hline 2002 & $1.28 \mathrm{E}-09$ & $-1.02 E-06$ & 0.0004 & -0.0913 & 18.7407 & -93.5687 & 3.998 \\
\hline 2003 & $5.90 \mathrm{E}-10$ & $-1.56 \mathrm{E}-07$ & 0.0000 & -0.0257 & 9.8678 & -103.5550 & 3.289 \\
\hline 2004 & $4.58 \mathrm{E}-10$ & $-4.20 \mathrm{E}-07$ & 0.0002 & -0.0708 & 14.2007 & -93.5324 & 2.821 \\
\hline 2005 & $1.63 \mathrm{E}-09$ & $-1.58 \mathrm{E}-06$ & 0.0006 & -0.1129 & 15.0607 & -62.9741 & 4.154 \\
\hline 2006 & $-1.30 \mathrm{E}-09$ & $1.45 \mathrm{E}-06$ & -0.0005 & 0.0486 & 6.9749 & -16.9268 & 2.648 \\
\hline 2007 & $-7.35 \mathrm{E}-10$ & $8.30 \mathrm{E}$ & -0.00 & 0.0020 & 9.9632 & -43.3877 & 3.202 \\
\hline 2008 & $-9.99 E-10$ & $1.02 \mathrm{E}$ & -0.00 & 0.0 & 8.3637 & 103.2701 & 2.951 \\
\hline 2009 & $7.96 \mathrm{E}-11$ & $-8.86 \mathrm{E}$ & 0.00 & -0.0779 & 15.4993 & -58.8958 & 2.621 \\
\hline 2010 & $7.80 \mathrm{E}-10$ & $\begin{array}{l}-1.29 \mathrm{E}- \\
-\end{array}$ & 0.0 & -0.1379 & 15.9118 & -84.8944 & 5.690 \\
\hline Average & 3.49E-12 & $9.31 \mathrm{E}-08$ & 0.0000 & -0.0445 & 13.8753 & -43.4940 & 4.449 \\
\hline
\end{tabular}

INPUT PARAMETERS

READ DATA

INPUT PARAMETERS

\begin{tabular}{|c|c|c|c|c|c|c|}
\hline Year & $\begin{array}{l}\text { Early dry } \\
\text { season }\end{array}$ & $\begin{array}{l}\text { Early wet } \\
\text { season }\end{array}$ & $\begin{array}{l}\text { Length of } \\
\text { dry season }\end{array}$ & $\begin{array}{l}\text { Peak of dry } \\
\text { season }\end{array}$ & $\begin{array}{c}\text { Annual } \\
\text { rainfall (mm) }\end{array}$ & $\begin{array}{l}\text { Maximum } \\
\text { rainfall }(\mathrm{mm})\end{array}$ \\
\hline 1989 & 121 & 318 & 197 & 251 & 1904 & 116 \\
\hline 1990 & 136 & 318 & 182 & 269 & 1869 & \\
\hline 1991 & 134 & 298 & 164 & 212 & 1450 & 89 \\
\hline 1992 & 113 & 255 & 142 & 182 & 2035 & 82 \\
\hline 1993 & 159 & 326 & 167 & 267 & 1827 & 102 \\
\hline 1994 & 135 & 298 & 163 & 208 & 1256 & 65 \\
\hline 1995 & & 303 & & 100 & 3899 & \\
\hline 1996 & 111 & 270 & 159 & 193 & 3584 & \\
\hline 1997 & 163 & 363 & 200 & 271 & 1353 & 58 \\
\hline 1998 & 124 & 268 & 144 & 199 & 2850 & 43 \\
\hline 1999 & 128 & 279 & 151 & 206 & 3024 & 73 \\
\hline 2000 & 135 & 297 & 162 & 212 & 2033 & 66 \\
\hline 2001 & 107 & 267 & 160 & 180 & 3206 & 89 \\
\hline 2002 & 160 & 345 & 185 & 273 & 1866 & 44 \\
\hline 2003 & 130 & 288 & 158 & 221 & 1776 & 65 \\
\hline 2004 & 143 & 338 & 195 & 252 & 1399 & 107 \\
\hline 2005 & 134 & 334 & 200 & 279 & 1759 & \\
\hline 2006 & $\frac{154}{155}$ & $\begin{array}{l}354 \\
358\end{array}$ & 203 & 244 & 1248 & 128 \\
\hline 2007 & $\begin{array}{l}155 \\
142\end{array}$ & 315 & 173 & 228 & $\begin{array}{l}1488 \\
1493\end{array}$ & \\
\hline 2008 & 124 & 280 & 156 & 202 & 1536 & 94 \\
\hline 2009 & 123 & 295 & 172 & 208 & 1386 & \\
\hline 2010 & 59 & 186 & 127 & 110 & 2137 & \\
\hline Average & 227 & 260 & 279 & 303 & 524 & \\
\hline Deviation & 616 & 611 & 606 & 598 & 830 & (5) \\
\hline
\end{tabular}

REPORT

ANALYSIS

Gambar 5. Aplikasi VBA untuk penentuan hari kering 
Tabel 1 Koefisien dan gradien untuk fungsi polinomial hujan kumulatif.

\begin{tabular}{|c|c|c|c|c|c|c|c|c|}
\hline Year & a5 & a4 & a3 & a2 & a1 & a0 & $\begin{array}{c}\text { dry season } \\
\text { gradient }\end{array}$ & $\mathbf{R}^{2}$ \\
\hline 1989 & $2,23 \mathrm{E}-09$ & $-2,17 \mathrm{E}-06$ & $8,58 \mathrm{E}-04$ & $-0,1795$ & 22,7724 & $-227,5643$ & 4,054 & 0,984 \\
\hline 1990 & $3,70 \mathrm{E}-09$ & $-3,36 \mathrm{E}-06$ & $1,16 \mathrm{E}-03$ & $-0,1977$ & 20,7179 & $-58,3635$ & 3,829 & 0,996 \\
\hline 1991 & $-1,76 \mathrm{E}-09$ & $1,75 \mathrm{E}-06$ & $-4,99 \mathrm{E}-04$ & 0,0143 & 11,7114 & $-44,7472$ & 2,694 & 0,993 \\
\hline 1992 & $-3,35 \mathrm{E}-09$ & 2,92E-06 & $-7,83 \mathrm{E}-04$ & 0,0487 & 9,2117 & 55,0341 & 4,375 & 0,997 \\
\hline 1993 & 1,35E-09 & $-1,13 \mathrm{E}-06$ & $3,67 \mathrm{E}-04$ & $-0,0688$ & 12,0508 & 41,5447 & 4,243 & 0,993 \\
\hline 1994 & $-2,71 \mathrm{E}-09$ & 2,57E-06 & $-7,74 \mathrm{E}-04$ & 0,0596 & 7,8977 & $-25,5268$ & 2,522 & 0,995 \\
\hline 1995 & 6,76E-09 & $-5,48 \mathrm{E}-06$ & $1,62 \mathrm{E}-03$ & $-0,2238$ & 24,3920 & $-139,1444$ & 9,087 & 0,996 \\
\hline 1996 & $-6,38 \mathrm{E}-10$ & $7,38 \mathrm{E}-07$ & $-1,61 \mathrm{E}-04$ & $-0,0259$ & 16,0865 & 9,5481 & 7,967 & 0,998 \\
\hline 1997 & $-1,90 \mathrm{E}-10$ & $4,02 \mathrm{E}-07$ & $-1,72 \mathrm{E}-04$ & 0,0001 & 10,3856 & 7,8969 & 3,078 & 0,995 \\
\hline 1998 & $-1,90 \mathrm{E}-09$ & $2,01 \mathrm{E}-06$ & $-6,82 \mathrm{E}-04$ & 0,0792 & 5,8015 & $-34,4524$ & 7,067 & 0,998 \\
\hline 1999 & $-2,54 \mathrm{E}-09$ & 2,77E-06 & $-9,02 \mathrm{E}-04$ & 0,0745 & 11,3917 & 48,3775 & 6,019 & 0,997 \\
\hline 2000 & $-1,71 \mathrm{E}-09$ & $1,70 \mathrm{E}-06$ & $-5,12 \mathrm{E}-04$ & 0,0300 & 10,5612 & $-8,2709$ & 4,624 & 0,995 \\
\hline 2001 & $-9,19 \mathrm{E}-10$ & $5,05 \mathrm{E}-07$ & $1,63 \mathrm{E}-04$ & $-0,1324$ & 27,7880 & $-128,6383$ & 6,950 & 0,995 \\
\hline 2002 & 1,28E-09 & $-1,02 \mathrm{E}-06$ & $3,51 \mathrm{E}-04$ & $-0,0913$ & 18,7407 & $-93,5687$ & 3,998 & 0,995 \\
\hline 2003 & $5,90 \mathrm{E}-10$ & $-1,56 \mathrm{E}-07$ & $1,15 \mathrm{E}-05$ & $-0,0257$ & 9,8678 & $-103,5550$ & 3,289 & 0,988 \\
\hline 2004 & $4,58 \mathrm{E}-10$ & $-4,20 \mathrm{E}-07$ & $2,08 \mathrm{E}-04$ & $-0,0708$ & 14,2007 & $-93,5324$ & 2,821 & 0,989 \\
\hline 2005 & 1,63E-09 & $-1,58 \mathrm{E}-06$ & $5,92 \mathrm{E}-04$ & $-0,1129$ & 15,0607 & $-62,9741$ & 4,154 & 0,992 \\
\hline 2006 & $-1,30 \mathrm{E}-09$ & $1,45 \mathrm{E}-06$ & $-5,18 \mathrm{E}-04$ & 0,0486 & 6,9749 & $-16,9268$ & 2,648 & 0,994 \\
\hline 2007 & $-7,35 \mathrm{E}-10$ & $8,30 \mathrm{E}-07$ & $-2,54 \mathrm{E}-04$ & 0,0020 & 9,9632 & $-43,3877$ & 3,202 & 0,993 \\
\hline 2008 & $-9,99 \mathrm{E}-10$ & $1,02 \mathrm{E}-06$ & $-2,85 \mathrm{E}-04$ & 0,0042 & 8,3637 & 103,2701 & 2,951 & 0,991 \\
\hline 2009 & 7,96E-11 & $-8,86 \mathrm{E}-08$ & $1,50 \mathrm{E}-04$ & $-0,0779$ & 15,4993 & $-58,8958$ & 2,621 & 0,991 \\
\hline 2010 & $7,80 \mathrm{E}-10$ & $-1,29 \mathrm{E}-06$ & $6,72 \mathrm{E}-04$ & $-0,1379$ & 15,9118 & $-84,8944$ & 5,690 & 0,997 \\
\hline Average & $3,49 \mathrm{E}-12$ & 9,31E-08 & 2,63E-05 & $-0,0445$ & 13,8753 & $-43,4940$ & 4,449 & 0,9937 \\
\hline
\end{tabular}

Hasil perhitungan yang dilakukan dengan menggunakan aplikasi polinomial (Gambar 3) menggunakan bahasa Visual Basic Aplication (VBA), didapatkan hubungan hujan kumulatif ratarata setiap hari seperti pada Persamaan (6):

$$
\begin{gathered}
Y=f(x)=3.49 \times 10^{-12} x^{5}+9.31 \times 10^{-8} x^{4}+2.63 \times 10^{-5} x^{3} \\
-0.0445 x^{2}+13.875 x-43.494
\end{gathered}
$$

Koefisien dari Persamaan (6) didapatkan dari rata-rata koefisien hujan kumulatif dari tahun 1989 hingga 2010. Pola hujan kumulatif dari dari tahun 1989 hingga 2010 dapat terlihat pada Gambar 6.

Rata-rata musim kemarau yang terjadi di Kota Serang dimulai pada hari ke 132 hingga hari ke 300 dengan lama rata-rata 168 hari. Awal musim kemarau dan hujan hasil simulasi memiliki nilai deviasi 23 untuk awal musim kering, 38 untuk awal musim hujan. Jika dilihat dati Tabel 2, kondisi demikian telah berlangsung dari tahun 1989 hingga
2009 dengan kisaran \pm 10 hari lebih cepat atau lebih lambat. Namun lain halnya yang terjadi pada tahun 2010 total curah hujan tahunannya $2.137 \mathrm{~mm}$, pada tahun tersebut gradien musim kering sebesar 5,69 $\mathrm{mm}$, dan musim kemarau memiliki rentang waktu yang relatif singkat, yakni pada hari ke 59 hingga hari ke 186. Pada tahun 2010 hujan tersebar merata sepanjang tahun hal ini dapat dilihat pada Gambar 7. Tidak ada garis yang relatif datar pada kurun waktu yang lama.

Hasil perhitungan ini dapat dijadikan acuan awal dan panjang musim kering, sehingga dapat ditentukan jumlah air untuk memenuhi berbagai kebutuhan baik untuk irigasi, domestik dan industri.

Hasil analisis menunjukkan pada rentang waktu antara hari ke-132 (11 Mei) hingga hari ke-300 (26 Oktober), sangat rentan terjadinya musim kemarau, namun nilai tersebut bisa lebih cepat atau lambat dengan kisaran 23 dan 38 hari. Puncak musim kemarau pada awal Juli sampai September. 




1990


2010



1995


Rata-rata

Gambar 6. Fugsi hujan kumulatif Kota Serang.

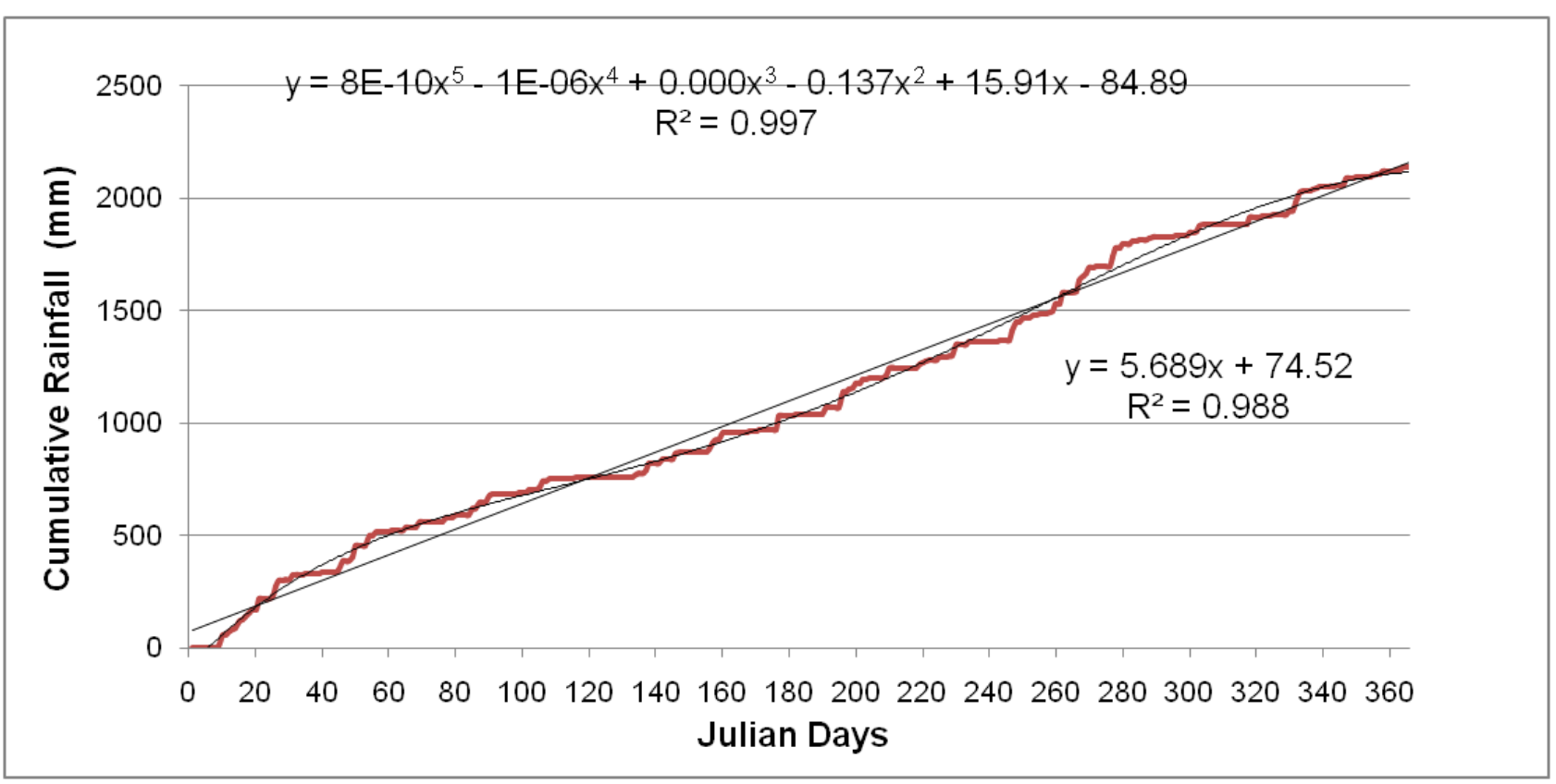

Gambar 7. Kondisi hujan kumulatif tahun 2010. 
Tabel 2. Hasil simulasi awal musim kemarau dan hujan untuk Kota Serang.

\begin{tabular}{ccccccc}
\hline Year & $\begin{array}{c}\text { Early dry } \\
\text { season }\end{array}$ & $\begin{array}{c}\text { Early wet } \\
\text { season }\end{array}$ & $\begin{array}{c}\text { Length of dry } \\
\text { season }\end{array}$ & $\begin{array}{c}\text { Peak of dry } \\
\text { season }\end{array}$ & $\begin{array}{c}\text { Annual rainfall } \\
(\mathbf{m m})\end{array}$ & $\begin{array}{c}\text { Maximum } \\
\text { rainfall (mm) }\end{array}$ \\
\hline 1989 & 121 & 318 & 197 & 251 & 1904 & 116 \\
1990 & 136 & 318 & 182 & 269 & 1869 & 98 \\
1991 & 134 & 298 & 164 & 212 & 1450 & 89 \\
1992 & 113 & 255 & 142 & 182 & 2035 & 82 \\
1993 & 159 & 326 & 167 & 267 & 1827 & 102 \\
1994 & 135 & 298 & 163 & 208 & 1256 & 65 \\
1995 & 167 & 303 & 136 & 258 & 3899 & 73 \\
1996 & 111 & 270 & 159 & 193 & 3584 & 88 \\
1997 & 163 & 363 & 200 & 271 & 1353 & 58 \\
1998 & 124 & 268 & 144 & 199 & 2850 & 43 \\
1999 & 128 & 279 & 151 & 206 & 3024 & 73 \\
2000 & 135 & 297 & 162 & 212 & 2033 & 66 \\
2001 & 107 & 267 & 160 & 180 & 3206 & 89 \\
2002 & 160 & 345 & 185 & 273 & 1866 & 44 \\
2003 & 130 & 288 & 158 & 221 & 1776 & 65 \\
2004 & 143 & 338 & 195 & 252 & 1399 & 107 \\
2005 & 134 & 334 & 200 & 279 & 1759 & 76 \\
2006 & 155 & 358 & 203 & 244 & 1248 & 128 \\
2007 & 142 & 315 & 173 & 228 & 1493 & 99 \\
2008 & 124 & 280 & 156 & 202 & 1536 & 94 \\
2009 & 123 & 295 & 172 & 208 & 1386 & 53 \\
2010 & 59 & 186 & 127 & 110 & 2137 & 70 \\
Average & 132 & 300 & 168 & 224 & 2040 & 81 \\
\hline Deviation & 23 & 38 & 21 & 40 & 756 & 830 \\
\hline & & & & & & \\
\hline
\end{tabular}

\section{KESIMPULAN}

Metode polinomial orde ke lima sangat tepat digunakan untuk menggambarkan hujan kumulatif setiap tahun dengan nilai $\mathrm{R}^{2}$ rata-rata 0,994. Ratarata musim kemarau yang terjadi di Kota Serang dimulai pada hari ke-132 hingga hari ke 300 dengan panjang rata-rata 168 hari. Awal musim kemarau dan hujan hasil simulasi memiliki nilai deviasi 23 untuk awal musim kering, 38 untuk awal musim hujan. Puncak musim kemarau terjadi pada awal bulan Juli hingga akhir bulan September.

\section{DAFTAR PUSTAKA}

[BMKG] Badan Meteorologi Klimatologi dan Geofisika Stasiun Klimatologi Pondok Betung Tanggerang, 2010, Analisis Musim Kemarau 2010 dan Prakiraan Musim Hujan 2010/2011 Provimsi Banten dan DKI Jakarta. Tanggerang: BMKG.

Bello N.J., Eruola A.O., Ufoegbune G.C. and Awomeso J.A. 2010. Evaluation of some empirical methods of estimatingpotential evapo-transpiration for determination oflength of growing season in a tropical wet and dryclimate. African J Agricultural Res. 5(16): 2116-2123.

Burden R.L. and Faires J.D. 1989. Numerical Analysis, Fourth Edition. Boston: PWS-KENT Publishing Company. hlm 841.

Chandra S., Ziemke J.R., Min W. and Read W.G. 1998. Effects of 1997-1998 El Nino on tropospheric ozone and water vapor. Geoph Res Lett. 25:38673870.

Edoga R.N. 2007. Determination of Length of Growing Season in Samaru Using Different Potential Evapotranspiration Models, AU J.T, 11(1):28-35.

Moron V., Robertson A.W. and Boer R. 2008. Spatial coherence and seasonal predictability of monsoon onset over Indonesia. J Climate. 21:1-11.

Ohara G., Takahasi H. and Yoshida T. 2005. A New Method for Determining the Planting Season Based on the Regional Climatic Environment of Crop Locality, J Agricultural Meteorology. 60(5):10811084.

Robert D.F., Wang Y., Roswintiarti O. and Guswanto. 2004. A drought-based predictor of recent haze events in western Indonesia. Atmospheric Environment. 38:1869-1878. 